\title{
Disparity of Ego-Identity Components in Relation to Psychological Security of Adolescents
}

\author{
Mosaad Abu Al Diyar ${ }^{1} \&$ Ashraf Atta M. S. Salem ${ }^{2}$ \\ ${ }^{1}$ Centre of Children Evaluation and Teaching, Kuwait \\ ${ }^{2}$ Faculty of Business Administration, Sadat Academy for Management Sciences, Egypt \\ Correspondence: Ashraf Atta M. S. Salem, Faculty of Business Administration, Sadat Academy for Management \\ Sciences, Egypt. E-mail: sirashrafams@hotmail.com
}

\author{
Received: February 9, 2015 Accepted: March 31, 2015 Online Published: July 27, 2015 \\ doi:10.5539/ies.v8n8p57 URL: http://dx.doi.org/10.5539/ies.v8n8p57
}

\begin{abstract}
The current study aimed at investigating the Ego-identity components and the disparity of these components in relation to the psychological security of adolescents in Egypt. The sample of the study consisted of (400) male and female adolescents. The researchers used two main instruments; the psychological security scale and the Ego-identity scale. Findings of the study revealed that there is a positive relationship between Ego-identity achievement and psychological security. It was also revealed that there is a negative relationship between Ego-identity look and Ego-identity dispersion on the one hand and psychological security on the other. Results also showed that there are statistically significant differences in the mean scores between adolescents with high and low Ego-identity in their psychological security in favor of adolescents with high Ego-identity. In addition, it was shown that there are statistically significant differences between low and high Ego-identity dispersion in psychological security in favor of low Ego-identity dispersion. Finally, it was revealed that there are statistically significant differences between adolescents with high and low Ego-identity in their overall score of Ego-identity.
\end{abstract}

Keywords: ego-identity, psychological security, adolescents

\section{Introduction}

\subsection{Introduce the Problem}

In spite of the large number of studies that deal with each of the study variables on its own, there are no studies that investigate the relationships between the study variables. The researchers reviewed the studies investigating the relationship between Ego-Identity and parental bringing up. Studies conducted in western countries correlate Ego-Identity with psychological security or social responsibility. Whereas studies conducted in Arab countries do not consider psychological security or social responsibility as an independent variable rather it is considered as one of the symptoms of other variables.

\subsection{Characteristics of Adolescents}

Adolescence is a distinguished period in a person's life to sum up his/her past and current experience to arrive at a sense of identity, which in turn will guide such person's future plans (Janarthanam \& Gnanadevan, 2014). Therefore, adolescence is the period that witnesses the sense of identity or rather Ego-Identity. Identityaccording to Erikson (1968)-is the central developmental task of adolescents and its resolutions set the social-cognitive structure of individuality. Identity is a life-long process emphasizing its normative crisis in adolescence. In the period of adolescence cognitive capacities increase, physical maturation and the imminence of taking on adult roles in society. With these indications, adolescents are confronted with the task of searching for a meaningful sense of self. This task is called "identity crisis" (Rituparna \& Anjali, 2008).

According to Kumru and Thompson (2003), a productive body of research on adolescent identity development has emerged during the past several decades stimulated by Marcia's (1966) operationalization of Erikson's (1968) portrayal of identity formation. Whereas Erikson described two outcomes of identity formation (identity achieved vs. identity diffused), Marcia delineated four identity statuses that are defined by the self-reported experiences of crisis and commitment. Identity achieved adolescents have made a personal commitment to an identity following a period of crisis or exploration. The moratorium status is characterized by the current exploration of alternatives but with no commitment. Foreclosed adolescents have experienced no crisis but have 
determined identity commitments (e.g., commitments have been adopted from others). Identity diffusion occurs when adolescents are confused or disorganized in their identity, and they experience no exploration that is likely to change this status. Erikson described how identity commitments can emerge in areas such as the choice of occupation, sex-role orientation, family roles, and in religious and political worldviews.

There are two dimensions of identity formation such as, crisis/exploration and commitment. The first component of identity is exploration which refers to an examination of alternatives with the intention to make a commitment. The second component of identity is the Commitment that refers to dedicating oneself to an action, goal, ideal, value or belief. Concerning the statues of identity, there are four identity statuses: 1) Adolescents who have experienced a period of crisis and made firm commitments to a set of values and goals they adopted during the period of exploration are the identity achievers. 2) Adolescents who are actively exploring alternatives, but who have not yet made a firm commitment called identity moratorium. 3) Adolescents who find their identity through the adoption of parental (or others) standards and values without examining the nature, quality, or personal fit of such commitments are called identity foreclosure. Finally, 4) adolescents who are neither exploring nor feeling the compulsion to find a self-defined identity are experiencing identity diffusion (Marcia, 1966).

Based on a constructivist theoretical perspective, Berzonsky $(1989,1990,1993)$ has developed a process-oriented paradigm of identity formation. According to Berzonsky, there are three distinct cognitive orientations, called identity styles, by which self-relevant information is evaluated, structured, revised, and utilized. The first style is the informational style that entails willingness to investigate multiple solutions to a given problem and to explore several options before committing to anyone. The second style is the normative style which represents growth by conforming to social and familial expectations and a high degree of commitment to authority and to the exercise of judgment. The third style is the diffuse/avoidant style that is marked by the tendency to procrastinate and to make decisions on a situation-by-situation basis. Based on such perspectives, the Informational style may be seen as the preferable course for identity formation as it will likely entail a greater openness to experience, action on the basis of deliberate reasoning, pursuit of decision-relevant information, and the exercise of greater ego control (Berzonsky, 1990 cited in Schwartz et al., 2000).

\subsection{Describe Relevant Scholarship}

In the following few lines light will be shed on the most prominent studies that have dealt with Ego-identity in relation to certain psychological variables. One of these studies conducted by Abdulrahman (1998) investigated the personality traits relating to four Ego-Identities. The sample of the study consists of 397 secondary and university students in Egypt with a mean age of 16-25 years. Instruments of the study included subjective the Scale of Ego-Identity Coping Style and the Clinical Analysis Scale. Results of the study reveal that there is a statistically significant positive correlation between Ego-Identity and emotional regulation and stability. It was also revealed that there is a significant positive correlation between interpersonal Ego-Identity achievement and self-efficacy. In addition, results have shown that there is a statistically significant correlation between Ego-Identity moratorium on the one hand and insecurity, sensitivity and stress on the other. A statistically significant negative correlation was detected between the first variable (Ego-Identity moratorium) and emotional stability, emotional control, emotional regulation and being adventurous. Findings of the study also revealed that there is a statistically significant correlation between Ego-Identity foreclosure and both visualization and self-efficacy whereas a statistically significant positive correlation has been revealed between Ego-Identity foreclosure and emotional stability. It is also found that high Ego-Identity achievers are high scorers in emotional stability, emotional control, adventures, self-regulation, insecurity compared with those who highly scored in Ego-Identity diffusion, Ego-Identity foreclosure and Ego-Identity moratorium.

A study was conducted by Al Ahmad (2001) in order to investigate problems young people and adolescents encounter. These problems included developmental problems (low-intensity problems), medium intensity and severe problems. Developmental problems include physical, psychological and social problems. Medium intensity problems include familial, school and vocational problems. Severe problems include Ego-Identity problems, alienation and drug addiction. The study also determined the psychological bases that help young people to overcome these problems.

On a related context, Owda (2002) investigated correlations between psychological and social climate, emotional tranquility and the power of Ego-Identity. The sample of the study consisted of (376) students at Islamic University, Gaza. The researcher used self-developed emotional tranquility scale. Results revealed that there is a statistically significant correlation between psychological/social climate and emotional tranquility. No statistically significant correlation was found in female students and emotional tranquility based on their majors.

Children's sense of psychological security acquired from their parents and anxiety and depression was 
investigated in the study of Mekheimer (2003). The sample of the study consisted of (206) male and female students. The researcher used Kerns Scale of Psychological Security. Results of the study revealed that there is a significant correlation between psychological security feeling and high symptoms of anxiety and threatening males and females. Findings also revealed that those children with low degrees of psychological security acquired from their parents were more passive in their future plans.

The correlation between psychological security and abuse of 331 primary school pupils (public and private schools) was assessed in the study of Abdel-Majeed (2004). The study used two main scales; the Psychological Security Scale and the Children Abuse Scale. Results of the study revealed that there is a statistically significant negative correlation between child abuse and a sense of psychological security. Male children are more abused than female children. It is also revealed that there are statistically significant correlations among gender, school type and psychological security.

In a related context, Al Khodary (2004) investigated psychological security levels of first aid workers in relation to some personality traits and other variables. The sample of the study consists of (123) workers in Gaza Governorate. The researcher developed a psychological security scale. Results of the study have revealed that first aid workers have medium levels of psychological security. It is also revealed that there is a positive correlation between psychological security, religious commitment and Ego-Identity power of first aid workers.

The correlation between psychological security and socio-political attitudes was investigated in a study conducted by Abu Owda (2006). The sample of the study consists of 256 male and female students at Azhar University. The researcher developed a Scale of Psychological Security. Results of the study revealed that there is a statistically significant correlation between psychological security and both piousness and liberality. No statistically significant differences were detected in psychological security feeling based on gender, major (science and human arts specialization) or academic achievement.

Tananuraksakul and Hall (2011) explored non-native English-speaking students' emotional security and dignity responses to their English language proficiency in an Australian context. Confidence is a source of emotional security bolstering dignity. Without it, students lack emotional security, diminishing their dignity when communicating with culturally different others. Emotional security and dignity have a synergistic relationship, in that lack of confidence emotionally threatens one's face, security and dignity. The study offers insights that help us to understand how international students' psychological well-being is affected by English performance

On a related context, Tryggvason (2012) conducted a study that aimed to explore how Finnish university-based subject teacher educators perceived their professional identity. Several factors related to professional identity were analysed. Subject teacher educators were initially subject teachers who have proceeded to the doctorate level. They form a small academic group within a larger faculty milieu with only partial responsibility for a teacher education programme. The study is based on focus group interviews with 15 subject teacher educators at four of the eight universities that offer teacher education in Finland. The results reveal that these teacher educators have a strong and persistent self-ascribed identity of an educational nature. The close social interplay with other subject teacher educators within the faculty seems to contribute to a confident collective identity. However, the self- identity is not congruent with the other-ascribed identity, which varies depending on the other party's institutional context. The subject teacher educators examined in this study wished to have research included to a higher extent in their identity as subject teacher educators.

In addition, Janarthanam and Gnanadevan (2014) investigated gender difference in the ego identity status of higher secondary students. The sample of the study consisted of (800) adolescents' students (410 boys and 390 girls) studying higher secondary education in Cuddalore District of Tamilnadu, India. The Ego-Identity Scale (including four identity status namely, identity achievement, identity moratorium, identity diffusion and identity foreclosure) consists of 40 items, 10 items in each identity status. Results indicated that the mean score of both boys and girls is higher in identity achievement rather than other statuses such as identity moratorium, identity foreclosure and identity diffusion. It further indicated that the overall identity status of girls is higher than the boys. The boys and girls differed significantly only in the identity foreclosure and identity diffusion, they do not differ significantly in other statuses. The mean score of girls is higher than the boys with respect to identity foreclosure and identity diffusion.

Kumru and Thompson (2003) examined the relationship between identity status and self-monitoring behavior including age and gender differences in these variables in 476 adolescents (15 to 22 years old) in Turkey-a non-Western society characterized by traditional and modernist culture elements. Identity was assessed with the Extended Version of the Objective Measure of Ego Identity Status, and self-monitoring was measured by the Self-Monitoring Scale. Identity and self-monitoring were significantly associated for ideological identity with 
identity-achieved students lowest and diffusion students highest in self-monitoring. There were no associations for interpersonal or general identity status. Consistent with research in North America, there were significant increases in identity achievement and moratorium with age and no gender differences in identity status. Males were significantly higher than females in self-monitoring, but there were no age differences. These findings are discussed in relation to the influences on identity formation in Turkey.

\subsection{Hypotheses of the Study and Their Correspondence to Research Design}

The current study tries to test the following hypotheses:

- There is a positive correlation between components of Ego identity and psychological security.

- There are statistically significant differences between higher and lower Ego identity in the students' feeling of psychological security.

- There are statistically significant differences between males and females in students' Ego identity and psychological security.

\section{Methods}

The current study used the descriptive research design. This research design helps in describing the phenomenon and holding comparisons among subjects of the study based on the study variables, Ego-Identity, and psychological security.

\subsection{Sample of the Study}

The psychometric sample of the study consists of 70university students; 35 male students and 35 female students with a mean age 16.30 and standard deviation of 1.09 years.

The basic sample of the study consists of 400 students of university in order to make sure of the validity, reliability and the psychometric efficacy of scales used in the study and to validate the correlational hypotheses of the study. This sample consists of (200) male students, (200) female students with age mean (16.06) and standard deviation (2.03) year.

\subsection{Research Design}

The current study followed the descriptive research design as it is the most suitable to the nature of the study. It is designed to investigate the differences between certain variables involved in the study. Also, the descriptive research design is not confined to just the description of the phenomenon but it also clarifies the relationships among variables.

\subsection{Instruments of the Study}

\subsubsection{Psychological Security Scale}

The psychological security scale (PSS) was developed by Raghdaa\& Noaisa (2012). It consists of 22 items with yes or no answers. The total score of the PSS is 44 marks whereas the lowest score is 22 marks which determine the presence or lack of psychological security.

\subsubsection{Ego-Identity Scale}

The Ego Identity Scale (EIS) was developed by Adams et al. $(1986,1989)$ and was translated into English by Al-Ghamdi (2010). Bennion and Adams (1986) and Adams et al. (1989) developed the objective measure of Ego Identity Status based on Marcia's (1966) view point that subsequently depends on Erikson (1968) theory. The scale consists of 64 items with eight items assigned for one of the four levels that lay under two main fields; Ideological and interpersonal Ego-Identity.

The scale is based on a Lickert-type five point scale consisting of strongly agree, agree, neutral, disagree and strongly disagree. The total score of the scale ranges from 8 to 48 marks. The dominant Ego-Identity rank is determined by comparing the participant's raw scores in each rank with the bench mark of this rank which equals the mean of the group added to the standard deviation (Adams, 1994). Participants falling under three Identity ranks are excluded in order to ascertain validity and reliability of the scale.

Groverant and Adams (1984), Bennion and Adams (1986) and Adams et al. (1984) calculated the validity and reliability of the scale for students in the United States of America. Abdelrahman (1988) standardized the Ego-Identity Scale in the Egyptian environment. Alghamdi (2000b) standardized the scale on the gulf environment. It indicated an accepted degree of validity and reliability. Test-retest reliability coefficients for Ego-Identity achievement (0.73), for Ego-Identity moratorium (0.79), Ego-Identity for closure (0.77) and Ego-Identity diffusion (0.79). 
Internal consistency coefficient of the scale was statistically significant, the correlation coefficients between scale items and the total score ranges from $(0.32)$ to $(0.64)$.After certain modifications, content validity of the scale was 0.94 which refers to the degree of agreement of members of jury. The beforehand mentioned content validity coefficient is an indicator of convergent validity paying attention to the ideological and interpersonal Ego-Identity discrepancy.

\subsection{Reliability of Study Tools}

Reliability coefficients for all scales used were calculated through three different methods

1) Alpha Cronbach Method which depends on the correlation coefficient of items among each other in each scale as well as the correlation coefficient between each item and the total score of the test.

2) Test-Retest Method. The test was administered twice with (15) minutes time interval between the two test sessions order to eliminate the effect or memorizing. This is to measure the reliability coefficient which is called stability coefficient which is influenced by error caused by discrepancy in evaluation.

\subsection{Construct Validity.}

Construct validity aims at investigating the correlation coefficients between the test components and the total score of the test.

Table 1 shows the reliability and Validity coefficients of males and females in the tests used in the study.

Table 1. Reliability and validity coefficient of ego-identity, and psychological security tests

\begin{tabular}{|c|c|c|c|c|c|c|c|}
\hline \multirow[b]{2}{*}{ Identity Types } & \multirow[b]{2}{*}{ Tests } & \multicolumn{3}{|c|}{ Means $(\mathrm{n}=60)$} & \multicolumn{3}{|c|}{ Females $(\mathrm{n}=60)$} \\
\hline & & Alpha & $\begin{array}{l}\text { Test } \\
\text { retest }\end{array}$ & $\begin{array}{l}\text { Construct } \\
\text { validity }\end{array}$ & Alpha & $\begin{array}{l}\text { Test } \\
\text { retest }\end{array}$ & $\begin{array}{l}\text { Construct } \\
\text { validity }\end{array}$ \\
\hline \multirow{4}{*}{$\begin{array}{l}\text { Ideological } \\
\text { Ego-Identity }\end{array}$} & $\begin{array}{l}\text { Ego-Identity } \\
\text { Achievement }\end{array}$ & 0.90 & 0.87 & $0.79 * *$ & 0.89 & 0.89 & $0.68 * *$ \\
\hline & $\begin{array}{l}\text { Ego-Identity } \\
\text { Moratorium }\end{array}$ & 0.88 & 0.86 & $0.72 * *$ & 0.85 & 0.78 & $0.41 * *$ \\
\hline & $\begin{array}{l}\text { Ego-Identity } \\
\text { Foreclosure }\end{array}$ & 0.86 & 0.84 & $0.67 * *$ & 0.77 & 0.87 & $0.44 * *$ \\
\hline & $\begin{array}{l}\text { Ego-Identity } \\
\text { Diffusion }\end{array}$ & 0.93 & 0.89 & $0.69 * *$ & 0.78 & 0.83 & $0.72 * *$ \\
\hline \multirow{4}{*}{$\begin{array}{l}\text { Interpersonal } \\
\text { Ego-Identity }\end{array}$} & $\begin{array}{l}\text { Ego-Identity } \\
\text { Achievement }\end{array}$ & 0.87 & 0.82 & $0.59 * *$ & 0.75 & 0.78 & $0.55 * *$ \\
\hline & $\begin{array}{l}\text { Ego-Identity } \\
\text { Moratorium }\end{array}$ & 0.88 & 0.84 & $0.81 * *$ & 0.89 & 0.82 & $0.70 * *$ \\
\hline & $\begin{array}{l}\text { Ego-Identity } \\
\text { Foreclosure }\end{array}$ & 0.91 & 0.90 & $0.64 * *$ & 0.83 & 0.84 & $0.69 * *$ \\
\hline & $\begin{array}{l}\text { Ego-Identity } \\
\text { Diffusion }\end{array}$ & 0.84 & 0.86 & $0.71 * *$ & 0.75 & 0.88 & $0.47 * *$ \\
\hline \multicolumn{2}{|c|}{ psychological security } & 0.82 & 0.86 & $(0.43 * *-0.77 * *)$ & 0.87 & 0.91 & $(0.46 * *-0.75 * *)$ \\
\hline
\end{tabular}

** Correlation is significant at the 0.01 level (2-tailed).

Close inspection of table (1) reveals high reliability coefficients for both male and female participants in the battery of tests of Ego-Identity, and psychological security. In addition, the estimate of the validity of the study variables reveals high Correlation between score total and all of sub test.

\subsection{Statistical Analysis}

Several statistical methods were used to answer the research questions posed in the study and to verify the study variables. The researchers used the statistical package of social science (SPSS) in order to work out the following: This must be written out in paragraph form to adhere to APA format 
1) Descriptive Statistics which include:

- Means and standard deviations

- Alpha Cronbach's Coefficient

- Pearson Correlation Coefficient.

2) Inferential Statistics which include:

- T-test to assess significance of mean difference of scores.

\section{Results}

\subsection{The Second Hypothesis}

Pearson Correlation Coefficient Significance Ego-Identity and psychological security.

Table 2. Pearson correlation coefficient significance $(\mathrm{N}=400)$

\begin{tabular}{lll}
\hline Identity Types & Tests & Psychological security \\
\hline \multirow{4}{*}{ Ideological Ego-Identity } & Ego-Identity Achievement & $0.288^{* *}$ \\
& Ego-Identity Moratorium & $-0.318^{* *}$ \\
& Ego-Identity Foreclosure & $-0.522^{* *}$ \\
& Ego-Identity Diffusion & $-0.694^{* *}$ \\
& Ego-Identity Achievement & $0.413^{* *}$ \\
Ego-Identity Moratorium & $-0.441^{* *}$ \\
Interpersonal Ego-Identity & Ego-Identity Foreclosure & $-0.312^{* *}$ \\
& Ego-Identity Diffusion & $-0.318^{* *}$ \\
& & $-0.294^{* *}$ \\
\hline
\end{tabular}

** Correlation is significant at the 0.01 level (2-tailed).

Table 2 shows the Pearson correlation coefficients between Ego-Identity and psychological security of the study participants $(\mathrm{N}=400)$. Close inspection of Table 2 reveals that there is a negative relationship between psychological security and Ego-Identity. In addition, the results revealed a positive relationship between psychological security.and Ego-Identity Moratorium, Ego-Identity Foreclosure, Ego-Identity Diffusion.

\subsection{The Second Hypothesis}

There are statistically significant differences between high and low ego-identity achievers on the psychological security in favor of the high ego-identity achievers.

Table 3. Mean scores, standard deviations and t-test values of High grades and Low grades in Ego-Identity and psychological security

\begin{tabular}{llccccc}
\hline \multirow{2}{*}{ Identity Types } & Tests & \multicolumn{4}{c}{ High grades (N=108) } & \multicolumn{2}{c}{ Low grades (N=108) } & \multirow{2}{*}{ T } \\
\cline { 2 - 5 } & Mean & $\begin{array}{c}\text { Std. } \\
\text { Deviation }\end{array}$ & Mean & $\begin{array}{c}\text { Std. } \\
\text { Deviation }\end{array}$ & \\
\hline & $\begin{array}{l}\text { Ego-Identity } \\
\text { Achievement }\end{array}$ & 28.36 & 2.34 & 17.21 & 1.82 & $39.07^{* *}$ \\
& $\begin{array}{l}\text { Ego-Identity } \\
\text { Moratorium }\end{array}$ & 16.62 & 2.03 & 31.08 & 2.71 & $44.37^{* *}$ \\
$\begin{array}{l}\text { Ideological } \\
\text { Ego-Identity }\end{array}$ & $\begin{array}{l}\text { Ego-Identity } \\
\text { Foreclosure } \\
\text { Ego-Identity }\end{array}$ & 19.12 & 4.28 & 27.41 & 6.35 & $11.25^{* *}$ \\
& 16.97 & 5.50 & 28.70 & 3.47 & $18.75^{* *}$ \\
\hline
\end{tabular}




\begin{tabular}{llccccc}
\hline & $\begin{array}{l}\text { Ego-Identity } \\
\text { Achievement }\end{array}$ & 32.79 & 3.25 & 12.69 & 3.36 & $44.61^{* *}$ \\
& $\begin{array}{l}\text { Ego-Identity } \\
\text { Interpersonal }\end{array}$ & 13.04 & 3.01 & 26.80 & 3.92 & $28.93^{* *}$ \\
Ego-Identity & $\begin{array}{l}\text { Moratorium } \\
\text { Ego-Identity }\end{array}$ & 12.60 & 2.77 & 29.16 & 3.36 & $39.50^{* *}$ \\
& $\begin{array}{l}\text { Foreclosure } \\
\text { Ego-Identity } \\
\text { Diffusion }\end{array}$ & 13.64 & 3.83 & 31.75 & 2.95 & $38.70^{* *}$ \\
\hline
\end{tabular}

** Significant at the 0.01 level (2-tailed).

* Significant at the 0.05 level (2-tailed).

Close inspection of Table 3 reveals that there are statistically significant differences between adolescents with high and low Ego-Identity scores in psychological security scale in certain components of Ego-Identity as follows:

Concerning Ideological and interpersonal Ego-Identity, it is revealed that there are statistically significant differences between high and low scorers in Ego-identity achievement in favor of adolescents with high scores. It is also revealed that there are statistically significant differences between adolescents with high and low scores in Ego-Identity diffusion in favor of adolescents with low scores.

\subsection{The Third Hypothesis}

Significance of Differences between males and females in Ego-Identity and psychological security.

Table 4. Mean scores, standard deviations and t-test values of males and females in ego-identity and psychological security

\begin{tabular}{llccccc}
\hline \multirow{2}{*}{ Identity Types } & Tests & \multicolumn{2}{c}{ Means } & \multicolumn{2}{c}{ Females } & T \\
\cline { 2 - 5 } & Mean & $\begin{array}{c}\text { Std. } \\
\text { Deviation }\end{array}$ & Mean & $\begin{array}{c}\text { Std. } \\
\text { Deviation }\end{array}$ & \\
\hline & $\begin{array}{l}\text { Ego-Identity } \\
\text { Achievement }\end{array}$ & 23.79 & 4.61 & 20.55 & 4.01 & $7.50^{* *}$ \\
& $\begin{array}{l}\text { Ego-Identity } \\
\text { Moratorium }\end{array}$ & 23.95 & 6.15 & 22.24 & 5.50 & $2.91^{* *}$ \\
& $\begin{array}{l}\text { Ego-Identity } \\
\text { Foreclosure }\end{array}$ & 22.36 & 5.54 & 22.15 & 6.08 & 0.369 \\
& Ego-Identity Diffusion & 21.67 & 7.03 & 20.46 & 6.27 & 1.82 \\
& $\begin{array}{l}\text { Ego-Identity } \\
\text { Achievement }\end{array}$ & 24.80 & 8.06 & 21.69 & 7.71 & $3.95^{* *}$ \\
Interpersonal & $\begin{array}{l}\text { Ego-Identity } \\
\text { Ego-Identity }\end{array}$ & 21.38 & 6.77 & 18.71 & 4.35 & $4.69^{* *}$ \\
& $\begin{array}{l}\text { Moratorium } \\
\text { Ego-Identity }\end{array}$ & 21.34 & 7.38 & 19.58 & 6.26 & $2.58^{*}$ \\
Foreclosure & Ego-Identity Diffusion & 24.73 & 7.79 & 21.06 & 6.30 & $5.17^{* *}$ \\
psychological security & 29.21 & 3.57 & 17.63 & 1.82 & $29.99^{* *}$ \\
\hline
\end{tabular}

** Significant at the 0.01 level (2-tailed).

* Significant at the 0.05 level (2-tailed).

Table 4 shows that there are statistically significant differences between males and females in the study variables as follows:

Concerning Ideological Ego-Identity, there are statistically significant differences between males and females in 
both Ego-Identity achievement and Ego-Identity moratorium in favor of males. Whereas, no statistically significant differences were detected between males and females in both Ego-Identity foreclosure and Ego-Identity diffusion.

Concerning interpersonal Ego-Identity, there are statistically significant differences between males and females in Ego-Identity achievement, Ego-Identity moratorium, Ego-Identity foreclosure, and Ego-Identity diffusion in favor of males. Concerning psychological security, it is revealed that there are statistically significant differences between males and females in favor of males.

\section{Discussion}

It is clear that the results of this study coincide with the studies reviewed. The current study revealed that there is a positive correlation between Ego-Identity achievement and psychological security that coincides with the studies conducted by Abdelrahman (1998), Dosoky (1995), Al Ahmed (2001) and Ossenfort (1998).

Results obtained from the current study coincide with the studies of Thomas et al. (2007), Smith (1978) which has revealed positive correlations between Ego-Identity diffusion on the one hand and psychological security on the other.

In addition, findings of the current study revealed that there are statistically significant differences between adolescents with high and low scores in Ego-Identity Scale to achieve personal security in favor of adolescents with high scores. Also, there are statistically significant differences between adolescents with high and low scores In Ego-Identity moratorium, Ego-Identity foreclosure, and Ego-Identity diffusion. These results seem to be logical. It is worth nothing that there is no single study conducted in any of the Arab countries that explored the statistically significance level between high and low Ego-Identity scores in psychological security and social responsibility.

Findings of the study have shown that there are statistically significant differences between males and females in favor of males in the sub-scales of Ego-Identity achievement and Ego-Identity moratorium. Whereas, there are no statistically significant differences between males and females in Ego-Identity foreclosure and Ego-Identity diffusion concerning Ideological Ego-Identity.

Results also have shown that there are statistically significant differences between adolescents with high and low scores in Ego-Identity moratorium, Ego-Identity foreclosure, and Ego-Identity diffusion.

Concerning interpersonal Ego-Identity, there are statistically significant differences between males and females in Ego-Identity achievement, Ego-Identity moratorium, Ego-Identity foreclosure and Ego-Identity diffusion in favor of male adolescents.

Concerning psychological security, there are statistically significant differences between males and females in favor of male due to the nature of male adolescents.

Findings of the current study coincide with results obtained by Janarthanam and Gnanadevan (2014) that indicated that the mean score of both boys and girls is higher in identity achievement rather than other statuses such as identity moratorium, identity foreclosure and identity diffusion. It further indicated that the overall identity status of girls is higher than the boys. The boys and girls differed significantly only in the identity foreclosure and identity diffusion, they do not differ significantly in other statuses. The mean score of girls is higher than the boys with respect to identity foreclosure and identity diffusion.

On the contrary to certain studies such as the one conducted of Owda (2002) which revealed that there is a statistically significant correlation between psychological/social climate and emotional tranquility. No statistically significant correlation was found in female students and emotional tranquility based on their majors.

Based on the results obtained from the current study in relation to literature reviewed, it is recommended that further researches to be conducted to investigate the relationship between variables under investigation with other age levels rather than adolescents.

\section{References}

Abdel-Moty, H. M. (1993). A study of some academic variables associated with Ego-Identity formation of university students. Journal of psychology, 11(5), 56-70.

Abdulrahman, M. A. (1993). Personality traits in relation to Ego-Identity coping styles of secondary schools and university students. Journal of Zagazig faculty of Education, 389-470.

Abdulrahman, M. A. (1998). A subjective Scale of Ideological and Interpersonal Ego-Identity rank in adolescence and early adulthood. Cairo: Dar Kebaa publishing house. 
Abdulrahman, M. A. (2000). Psychological and mental Disorders and Diseases. Cairo: Dar Kebaa publishing house.

Al Ahmed, A. (2001). Problems of youths and their needs in a changing world. Journal of college of human studies. Azhar university, 2(19), 35-44.

Al Beheiry, A. (1989). Ego-Identity in relation to anxiety, self-esteem and parental bringing up of university students: A study in the light of Erickson theory. Journal of Zagazig faculty of Education, 12(21), 165-211.

Al Dawash, F. (2000). Ego-Identity status of adolescents in relation to their attitudes towards parents and school staff members (Unpublished Ph. D. Institute of Educational studies, Cairo University).

Al Ghamdi, H. A. (2001). Ego-Identity formation in relation to the development of moral thinking of a sample of adolescents and youths in the Western Region, kingdom of Saudi Arabian. Egyptian Journal of psychological studies, 8(29), 221-255.

Al Mezil, A. F. (1999). Ego-Identity: comparative study between delinquents and non-delinquents. Journal of psychological studies, 21(1), 131-137.

Cui, M., Conger, R. D., Bryant, C. M., \& Elder Jr., G. H. (2002). Parental behavior and the quality of adolescent friendship: A serial-contextual perspective. Journal of Marriage and Family, 64, 676-689. http://dx.doi.org/10.1111/j.1741-3737.2002.00676.x

Dosoky, K. (1985). Psychology and Consistency Study (3rd ed.). Zagazig faculty of Education, Egypt.

Dosoky, K. (1988). Definition of Psychology Terms (Part 1). Cairo: International House for publishing and Distribution.

Dosoky, R. (1995). A comparative study of some personality traits of rehabilitation institutions and normal family children. Journal of psychology, 36(9).

Erikson, E. H. (1968). Identity: Youth and Crisis. New York: Norton.

Erikson, E. H. (1968). Identity: Youth and Crisis. New York: Norton \& Company Inc.

Ismail, A. A. M. (1989). A study of some parental bringing up responsible for enhancing aspiration level in the light of some demographic variables (Unpublished MA thesis). Faculty of Arts, Tanta University.

Janarthanam, D., \& Gnanadevan, R. (2104). Gender Differences in Ego-Identity Status of Higher Secondary Students. International Journal of Teacher Educational Research (IJTER), 3(2), 14-18.

Kumru, A., \& Thompson, R. (2003). Ego-identity Status and Self-Monitoring Behavior in Adolescents. Journal of Adolescent Research, 18(5), 481-495. http://dx.doi.org/10.1177/07435558403255066

Marcia, J. E. (1967). Ego-Identity status: relationship to change in self-esteem, general mad-adjustment and $\begin{array}{lllll}\text { authoritarianism. Journal of } & \text { Personality, } & 35, & 119-133 .\end{array}$ http://dx.doi.org/10.1111/j.1467-6494.1967.tb01419.x

Marcia, J. E. (1983). The Relational Roots of Identity. In J. Kroger (Ed.), Discussions on Ego Identity (pp. 101-120). Hillsdale, NJ: Lawrence Erlbaum.

Mohamed, A. A. (1991). A comparative study of self-esteem among university youth based on their Ego-identity coping styles. Journal of Zagazig faculty of Education, 14, 1-40.

Morsi, A. M. M. (1988). A comparative study of anxiety level in relation to Ego-Identity of smokers and non-smokers adolescents (Unpublished MA Thesis). Zagazig faculty of Art. Zagazig University.

Othman, S. A. (1979). Social responsibility and Muslims. Cairo: Anglo-Egyptian publishing House.

Othman, S. A. (1986). Participation as an element of social responsibility. Journal of Educational studies, Institute of Educational studies, Cairo University, 4.

Rituparna, B., \& Anjali, Gh. (2008). Ego-Identity Status and Its Relationship with Self-Esteem in a Group of Late Adolescents. Journal of the Indian Academy of Applied Psychology, 34(2), 337-344.

Rutter, M. (1990). Psychological resilience and protective mechanisms. In J. Rolf, A. Masten, D. Cicchetti, K, Nuechterlein, \& S. Weintraub (Eds.), Risk and Protective factors in the development of psychopathology (pp.181-214).

Schwartz, S., Mullis, R., Waterman, A., \& Dunham, R. (2000). Ego Identity Status, Identity Style, and Personal Expressiveness: An Empirical Investigation of Three Convergent Constructs. Journal of Adolescent Research, 15(4), 504-521. http://dx.doi.org/10.1177/0743558400154005 
Shokair, Z. (1996). The predicting value of some clinical case of psychological well-being, optimism, pessimism and death anxiety. Journal of Tanta Faculty of Education, (23).

Tananuraksakul, N., \& Hall, D. (2011). International Students' Emotional security and Dignity in an Australian Context: An Aspect of psychological Well-Being. Journal of Research in International Education, 10(2), 189-200. http://dx.doi.org/10.1177/1475240911410784

Tarrah, A. (2000). Social bringing up (socialization) and male values in Kuwaiti society. Journal of Social Sciences, 28(2), 26-47.

Thomas, J. S. B., O’Bryan, K. A., O’Neill, T. M., \& Hector, D. (2007). Choline Supplementation Following Third-Trimester-Equivalent Alcohol. The American Psychological Association, 121(1), 120-130.

Tryggvason, M. (2012). Perceptions of identity among Finnish University-Based Subject Teacher Educators. European Journal of Teacher Education, 35(3), 289-303. http://dx.doi.org/10.1080/02619768.2011.633998

\section{Copyrights}

Copyright for this article is retained by the author(s), with first publication rights granted to the journal.

This is an open-access article distributed under the terms and conditions of the Creative Commons Attribution license (http://creativecommons.org/licenses/by/3.0/). 